\title{
https://valleyinternational.net/index.php/theijsshi/index
}

\section{Instagram Platform Optimization By (Technology Acceptance Model) Approach As Improvement Of Mozarella Marketing Performance At Covid-19 Pandemic Era}

\author{
A.E. Kusumastuti ${ }^{1}$, J.A. Putritamara ${ }^{1}$, S. Azizah ${ }^{1}$, Divia ${ }^{2}$ \\ ${ }^{1}$ Livestock Socio-economics Department, Faculty of Animal Science, Brawijaya University, Malang 65145, \\ East Java Province,Indonesia \\ ${ }^{2}$ Student of undergraduate in Faculty of Animal Science, Brawijaya University, Malang 65145, East Java \\ Province, Indonesia
}

\begin{abstract}
The change of consumers' behaviors during pandemic is a challenge for livestock products producers to survive among sector threats that are often unpredictable by producers. Such change demanded the producers to be more adaptive and sensitive to consumers' behaviors, so that most of producers used traffic analysis as basic to identify the consumers' behaviors in diverse condition. High level of technological use during pandemic is an opportunity for the producers to optimize platform used by majority of the market segmentation. The research purpose was optimizing marketing strategy via Instagram as improvement of SMEs-scale Mozarella marketing performance. The research methods used were survey and interview with consumers who use Instagram, 100 peoples, and then analyzed using Multiple Regression as basic in composing strategies. Results of the analysis showed that $87 \%$ TAM positively affected on intention of the consumers to purchaseMozarella cheese via Instagram. Indicator that dominates high effect of both elements is ease to use. It indicates that consumers who majority are native digital consumers, prefer to use Instagram because they are pro to Instagram features, which is assumed to be easy for landing page when they have purchasing transaction.
\end{abstract}

Keywords: Instagram, mozzarella cheese, marketing, Technology Acceptance Model (TAM)

\section{Introduction}

By the end of December 2019, the world caused a commotion as the finding of Coronavirus 2019 (Covid19), infection (SARS-CoV-2) in the bottom part of the respiratory tract, which was detected for the first time in Wuhan, Central Hubei Province, China. Furthermore, the rate of Covid-19 dispersion was difficult to be controlled. Since World Health Organization (WHO) settled on Covid-19 as the world pandemic, many countries have anticipated to prevent the spread of Covid-19 (Sumbaga and Selia, 2021). The global community also strove for reducing the spread of Covid-19. Global lockdown, social distancing, and other steps have been introduced to restrict the spread of Covid-19 pandemic, and it urged the consumers to purchase more in online marketplaces (Shengyu,et. al., 2021). Some countries decided to close in and out access of international routes, including Indonesia. All activities were temporarily suspended, including exports and imports, which have caused global economy to be at a critical point. The Indonesian government has setpolicies of social activities and territorial restrictions, in which most of the community activities can only be done in house. By the issuance of policies from the government, it forced the community to be able to adapt to the new habits, so that it may change the consumers' behaviors in Indonesia. The pandemic of Covid-19 has changed the ways how we work, communicate and purchase unexpectedly, more than other interference in this decade. As reflected in the sales economic data analysis, such dramatic situation highly affected attitudes and behaviors of the consumers (Crosta,et. al., 2021). 


\section{A.E. Kusumastuti.et al. /Instagram Platform Optimization By (Technology Acceptance Model) Approach As Improvement Of Mozarella Marketing Performance At Covid-19 Pandemic Era}

During the pandemic of Covid-19, it caused significant change on consumers' behaviors. The most obvious thing was high intensity in using technology due to almost the whole activities of the community were only done at home, such as working, learning, shopping, and etc. Other changes in consumers' purchasing behaviors related to physical sales point. Such change occurred as the consumers aimed to reduce the trip to the physical stores (Cardenas,et. al., 2021). Due to total lockdown in some countries such as India, South Korea, China, Italy, and other countries, consumers could not go shopping to store selling notions or shopping centers. On the contrary, the stores come to the house. It also prevails on job and education (Sheth, 2020).In fulfilling consumption of daily needs during pandemic, the communities frequently use online application, in which we just have to wait and the products will be delivered to our houses. Starting from a necessity in a pressure, it becomes a habit that gradually begins to attach and becomes a normal thing. In general, we prefer comfort and practical in doing anything, including in fulfilling the daily needs, particularly foods. Consumers stated that they feel comfortable and practical with purchasing system through online application. Online shops are not able to provide the entire needs as in traditional/physical shops. The consumers' needs that could not be found in online shops include the need to see, touch, and perceive quality of the product directly (Sayyida,et. al., 2021). With the advances in technology, the producers are insisted to be up-to-date and upgraded and should not be outdated. Particularly for producers of livestock products who tend to have ups and down during pandemic. Producers of the livestock products should be more adaptive and innovative in facing the consumers' behaviors changes which are frequently unpredictable.

Rapid development of the era makes technology also develop rapidly. Today, we live in an era where everything relies on sophisticated technology. It is undeniable that now many digital media applications have been created and launched that can ease the human burden. Therefore, it requires a study of Technology Acceptance Model (TAM) that adopts the Theory of Reasoned Action (TRA). TAM is a method to measure and learn the individual behavior as the user of technology in accepting and using the offered technology. The concept of TAM was developed from psychological theory, which was based onbelief, attitude, intention, and user behavior relationship.According to the most of the researchers, TAM is considered as the most appropriate concept to determine readiness of the group to carry out basic computer technology in their activities (Rahmawati and Narsa, 2019). TAM which is adopted in this study, includes perceived usefulness, perceived ease of use, attitude toward using, and behavioral intention to use (Wikarsa and Apriandy, 2021). Based on references of the theory, survey and interview will carried out toward consumers as Instagram users, 100 peoples, to learn the individual behavior and find out intention to purchase mozzarella cheese through Instagram.

As we have already known, the use of social media has increased, particularly during pandemic. Age has no longer become the problem; the social media user is individual in the community. Social media can be used as means of education, entertainment, keep in touch with friends and family, do business, and etc. Therefore, producers try to make a profit through social media. It is started from Facebook, Instagram, WhatsApp, Twitter, and Line. It is due to most of physical and social activities arte restricted, whereas online platform has become tools for business (Syaifulah,et. al., 2021). However, it seems that Instagram is the most popular among communities, so that Instagram is the right choice to sell products as it is the most complete platform along with its complete features. This is the reason why this study chooses to use Instagram platform. It was not only shortening time because it was easier to find respondents and interact with each other, it also sped up in drawing conclusions from the results of the research. The research showed positive relationship between high social activities (traveling, going to sporting, visiting friends, etc.) with the motivation of using Instagram as a means of documentation. As a result, it would be better to use Instagram than other platforms in transactions, including in business (Anwar,et. al., 2020).

Funneling in marketing is one of online-marketing technique that could change stranger into consumer. Mechanism of the funneling strategy was begun by gathering as many potential consumers as possible, then see and sort out the consumers who are really interested in the product.

In general, funneling has several steps as follows: Firstly,Awareness, in which the consumers realize and 


\section{A.E. Kusumastuti.et al. /Instagram Platform Optimization By (Technology Acceptance Model) Approach As Improvement Of Mozarella Marketing Performance At Covid-19 Pandemic Era}

recognize a product that conforms to their needs. Secondly, research, in which the consumers learn the product, so that they have more knowledge about the products or services. Thirdly,Decision, in which the consumers decide their choice on a brand among the same products. The final step is Purchasing, in which the consumers recognize the product and the specific brand as desired, and in general, they concern about the price, convenience in ordering, or comparing with other products before purchasing (Jansen and Simone, 2011). Other opinion suggested that consumers have passed through 4(four) stages of cognition and action when they decide what product or service that will be purchased. Specifically, consumers (1) become aware of the product or service, (2) examine their choices, (3) make a decision, and (4) purchase the chosen product (Doshi,et. al., 2017). If consumers are satisfied on the offered products, in general, they will repeatedly purchase the product, and it is not impossible if the product will recommend to their families or relatives. So, the most important is the first impression, particularly quality of the product.

\section{Methods \\ Research Method}

The research method used a case study on one of MSMEs in Malang that produces mozzarella cheese and adopt social media as consumer engagement strategy. A case study applied in this research that is only focused on one particular object and then studied in a limited period of time as a case. In general, case study combines the data collecting methods such as documents (archives), interview, questionnaires, and observation.

\section{Data Collection Method}

To collect the data, the researcher used quantitative and qualitative methods (Sobari and Husnussalam, 2019) through survey, directly observation, and interview to respondents. This method trains creative thinking skills (sensitivity, fluency, flexibility, originality, and elaboration) that refer to wider use of the mind. Methodology of the qualitative case study enables the researcher to explore deeply the complicated phenomena in some specific contexts. Some of a problem frequently causes confusion, such as wasting time, and wrong decision, which affect the whole results of the study (Rashid,et. al., 2019).

\section{Research Sample Technique}

The research sample wasconsumers that become the market segmentation of mozzarella cheese brand $\mathrm{X}$ around 100 respondents determined by purposive sampling, withthe criteria of the consumers as respondents of the research who purchased with frequency above 3 times via landing page in Instagram (Ig) and the second requirement with a minimum age category of 18 to 35 years old.

Purposive sampling technique is used with certain considerations. The used or taken samples were not based on strata, random, or region, but they were based on a research purpose. Purposive sampling is used when a researcher wants to target an individual with characteristic of interest in research (Tumer, 2020). The reason of purposive sampling was due to the samples are more suitable with intention and purpose of the research, so that it will increase accuracy of the research and trust of the data and the results. Four aspects of the concept that have been described previously are as follow: credibility, transferability, dependency, and confirmation (Campbell et al., 2020). This method can use limited primary data, and it is the most economic and efficient method. The decision to intentionally select a sample of primary studies for inclusion in the synthesis of qualitative evidence has its own advantages and disadvantages. This allows us to achieve a fairly wide geographic spread of the primary studies while limiting the number of studies included in the system. This allows us to include studies with rich data and studies that are most similar to the puspose of the synthesis (Ames et al., 2019).

\section{Data analysis using multiple-regression}

Regression analysis is a statistical technique to estimate relationship among variables that have the reason and result relationship. The regression model with one dependent-variable and more than one independentvariable are so-called multiple-regressions(Uyanik and Guler, 2013). The calculation of multiple-linear regression is started with pre-data processing by eliminating attributes, records, and data clearing 


\section{A.E. Kusumastuti.et al. /Instagram Platform Optimization By (Technology Acceptance Model) Approach As Improvement Of Mozarella Marketing Performance At Covid-19 Pandemic Era}

(Kurniatullah and Pramudi, 2017). Regression analysis is more emphasized on questions about statistical inference such as how much uncertainty in the curve corresponds to the experience of the data with random error (Tamrakar,et. al., 2021). Independent variable values from multiple-regression are used to predict the single dependent value. The least squares method will obtain a system of linear equations that can be formed into matrix multiplication. Calculation of the regression coefficient values can be solved by system solution using Gauss's Elimination. Calculation is assisted by the tools of Matlab 2016b, and the results are compared to values which were obtained by the tools assistance of Minitab 18. Regression model can be measured from coefficient of determination $\left(R^{2}\right)$ values that range between 0 and 1 . If the value approaches to 1 , it means that the independent values highly affect on the dependent values, which means that the applied model is favorable to describe the variable's effect.

The theoretical concept of the study applied the accepted model technology approach, which means that to what extent the consumers accept the technology offered by the producers to reach the products, which are going to be purchased.

Table 1. Variable, indicator and item in TAM approach

\begin{tabular}{|c|c|c|}
\hline Variable & Indicator & Item variables \\
\hline \multirow[t]{3}{*}{$\begin{array}{l}\text { Perceived usefulness (XI) } \\
\text { Davis et al., (1989) simply } \\
\text { described as one's tendency } \\
\text { to use an application and } \\
\text { believed that this } \\
\text { perception will assist him to } \\
\text { do a better job }\end{array}$} & $\begin{array}{l}\text { Performance } \\
\text { Improvement }\end{array}$ & $\begin{array}{l}\text { 1. Use the instagram adds feature to find out the } \\
\text { traffic audiences, so that producers will be able to } \\
\text { analyze the consumers' journey } \\
\text { 2. Use the instagram shop that facilitates the } \\
\text { consumers landing page to website } \\
\text { 3. Use audio visual features such as reels, template } \\
\text { instagram story, and highlight to have } \\
\text { engagement with audiences }\end{array}$ \\
\hline & $\begin{array}{l}\text { Work system } \\
\text { effectiveness }\end{array}$ & $\begin{array}{l}\text { 1. Instagram assists the producers to enter the } \\
\text { scheme of low cost high impact } \\
\text { 2. Instagram facilitates the consumers landing page } \\
\text { to website and marketplace } \\
\text { 3. Insta story is used to give feedback top the } \\
\text { consumers when they visit the producers }\end{array}$ \\
\hline & $\begin{array}{l}\text { Practicality in } \\
\text { access }\end{array}$ & $\begin{array}{l}\text { 1. It is the most practical platform which is mostly } \\
\text { owned by the native digital consumers because } \\
\text { Instagram has almost the whole platform features, } \\
\text { as well as audio visual and chat Instagram }\end{array}$ \\
\hline \multirow[t]{3}{*}{$\begin{array}{l}\text { Behavioral Intention to Use } \\
(X 2)\end{array}$} & $\begin{array}{l}\text { Have helpful } \\
\text { features }\end{array}$ & $\begin{array}{l}\text { 1. Audio visual features in Instagram facilitate the } \\
\text { producers to design promotion in accordance with } \\
\text { characters/behaviors of the market segmentation } \\
\text { 2. Instagram features are easy to be used by the } \\
\text { beginner } \\
\text { 3. Use hashtag insight to analyze hashtag that has } \\
\text { the greatest impact so that producers will figure } \\
\text { out the consumers' behaviors in searching for the } \\
\text { related products }\end{array}$ \\
\hline & $\begin{array}{l}\text { Continue in the } \\
\text { future }\end{array}$ & $\begin{array}{l}\text { 1. Features in Instagram are always up-to-date along } \\
\text { with development of technology and market } \\
\text { trend, conform to the changing consumers' } \\
\text { behaviors who prefer simple system to reach the } \\
\text { products in short time }\end{array}$ \\
\hline & Always try to use & $\begin{array}{l}\text { 1. Capacity in using native digital consumer is quite } \\
\text { high in Instagram because of practical and as } \\
\text { needed }\end{array}$ \\
\hline $\begin{array}{l}\text { Perceived Ease Of Use } \\
(X 3)\end{array}$ & $\begin{array}{l}\text { Easy to use } \\
\text { Instagram }\end{array}$ & $\begin{array}{l}\text { 1. Ease to register the business account } \\
\text { 2. Instagram assists the user to post } 10 \text { photos }\end{array}$ \\
\hline
\end{tabular}


A.E. Kusumastuti.et al. /Instagram Platform Optimization By (Technology Acceptance Model) Approach As Improvement Of Mozarella Marketing Performance At Covid-19 Pandemic Era

\begin{tabular}{|c|c|c|}
\hline \multirow{3}{*}{$\begin{array}{l}\text { According to Davis } \\
\text { (1989) accessibility } \\
\text { perception or perceived } \\
\text { ease of use (PEOU) is } \\
\text { described as a person's } \\
\text { level of belief that the use } \\
\text { of technology will reduce } \\
\text { excessive efforts }\end{array}$} & & $\begin{array}{l}\text { simultaneously } \\
\text { 3. Hashtag and location features assist the } \\
\text { consumers to search for information } \\
\text { 4. Instagram does not only provide audio visual, but } \\
\text { also chat-based feature that make the interaction } \\
\text { become easier }\end{array}$ \\
\hline & Easy to adapt & $\begin{array}{l}\text { 1. Easy to make new friends and inspirations to } \\
\text { develop the business products }\end{array}$ \\
\hline & $\begin{array}{l}\text { Interaction takes } \\
\text { place clearly and } \\
\text { understandable }\end{array}$ & $\begin{array}{l}\text { Caption in Instagram assists producers and } \\
\text { consumers to interact and share information }\end{array}$ \\
\hline \multirow[t]{3}{*}{ Attitude Toward Using $(Y)$} & pleased to use & 1. Audio visual supports the promotion activities \\
\hline & Enjoy the use & $\begin{array}{l}\text { 1. Higher aesthetical value in Istagram than other } \\
\text { platforms, so that the audiences prefer Instagram } \\
\text { to other platforms }\end{array}$ \\
\hline & $\begin{array}{l}\text { Interaction } \\
\text { convenience }\end{array}$ & $\begin{array}{l}\text { 1. Instagram assists to maintain the privacy of } \\
\text { producers and consumers when interacting via } \\
\text { direct message (DM) }\end{array}$ \\
\hline
\end{tabular}

\section{Results and Discussions:}

\section{Characteristics of the Millennial Consumer}

Majority of the native digital consumers are $\mathrm{Y}$ and $\mathrm{Z}$ generations as potential resources who have great power to affect other consumers as sales conversion optimization strategy. High ability of the native in marketing advocacy is a strategic step of the producers to offer good services in the midst of producer limitations during the pandemic. High relevance between consumers and products during pandemic is a favorable alternative to have positive effect for producers to survive under high health-stress. It relates to high demand for products that support the consumers' health. During pandemic, livestock products become the alternative for consumers because they are believed as immunomodulator along with high product diversification. One of them is dairy product, which is processed into various products with added values. Milk as livestock products has high proporsition for consumers, particularly in supporting the health aspect, but deficiency of the product is perishable, so that producers initiate to maintain the value chain to the consumers by processing it into cheese. Cheese is an additional food for Indonesian people which is not a main priority because the product is elastic in price. Basically, cheese is not a primary product, but it becomes a consideration for native digital consumers to get new experiences for the users based on the perspective of the highest needs as introduced by Maslow's theory of needs in which the need to actualize oneself when they decide to purchase the products as what they want.

Table 1. Results of Validity Test

\begin{tabular}{|c|c|c|c|c|}
\hline Parameter & Item & r-table & r-count & Description \\
\hline \multirow[t]{3}{*}{ Perceived usefulness $\left(\mathrm{X}_{1}\right)$} & $\mathrm{X} 1.1$ & \multirow{3}{*}{0,195} & 0,866 & Valid \\
\hline & $\mathrm{X} 1.2$ & & 0,852 & Valid \\
\hline & $\mathrm{X} 1.3$ & & 0,843 & Valid \\
\hline \multirow{3}{*}{$\begin{array}{l}\text { Behavioral Intention to Use } \\
\left(\mathbf{X}_{2}\right)\end{array}$} & $\mathrm{X} 2.1$ & \multirow{3}{*}{0,195} & 0,756 & Valid \\
\hline & $\mathrm{X} 2.2$ & & 0,774 & Valid \\
\hline & $\mathrm{X} 2.3$ & & 0,712 & Valid \\
\hline \multirow[t]{4}{*}{ Perceived Ease of Use $\left(X_{3}\right)$} & $\mathrm{X} 3.1$ & \multirow{4}{*}{0,195} & 0,689 & Valid \\
\hline & $\mathrm{X} 3.2$ & & 0,743 & Valid \\
\hline & X3.3 & & 0,725 & Valid \\
\hline & $\mathrm{X} 3.4$ & & 0,791 & Valid \\
\hline \multirow[t]{3}{*}{ Attitude Toward Using (Y) } & Y.1 & \multirow{3}{*}{0,195} & 0,798 & Valid \\
\hline & Y.2 & & 0,812 & Valid \\
\hline & Y.3 & & 0,844 & Valid \\
\hline
\end{tabular}


Validity test is a test used to show the extend to which the measuring instrument used in a measure is what is being measured. Ghozali (2009) stated that the validity test used to measure the validity or invalidity of a questionnaire. A questionnaire is said to be valid if the question is able to reveal something that will be measured by the questionnaire. An item in a research instrument is said to be valid if it has a correlation to the total score of the question items, which is a correlation value $>r$ table. Table 1 reveals that all variables are valid

\section{Table 2. Results of Reliability Test}

\begin{tabular}{|l|c|c|c|}
\hline \multicolumn{1}{|c|}{ Parameter } & Item & Cronbanch's alpha value & Description \\
\hline Perceived usefulness $\left(\mathbf{X}_{\mathbf{1}}\right)$ & $\mathrm{X}_{1}$ & 0,832 & Reliable \\
\hline Behavioral Intention to Use $\left.\mathbf{( X}_{\mathbf{2}}\right)$ & $\mathrm{X}_{2}$ & 0,759 & Reliable \\
\hline Perceived Ease of Use $\left(\mathbf{X}_{\mathbf{3}}\right)$ & $\mathrm{X}_{3}$ & 0,778 & Reliable \\
\hline Attitude Toward Using $(\mathbf{Y})$ & $\mathrm{Y}$ & 0,807 & Reliable \\
\hline
\end{tabular}

Instrument reliability characterizes the level of consistency (Janti, 2014). Furthermore, Sugiharto and Situnjak (2006) states that reliability refers to an understanding that the instruments used in research to obtain information used can be trusted as a data collection tool and are able to reveal the actual information in the field. A questionnaire is said to be reliable or not reliable if a person's answer to the statement is consistent or stable from time to time. The reliability of a test refers to the degree of stability, consistency, predictability, and accuracy. Measurements that have high reliability are measurements that can produce reliable. The value of a good reliability coefficient according to Cronbach Alpha is stated good if above 0.7 (good enough), and 0.8 (good). Table 2 showed that all variable is $>0.7$, so that reliable.

\section{Table 3. Results of Multiple Regression Analysis}

\begin{tabular}{|l|c|}
\hline Variable & Coefficient of Regression \\
\hline Constant & 87,910 \\
\hline Perceived usefulness $\left(\mathrm{X}_{1}\right)$ & $0,456^{*}$ \\
\hline Behavioral Intention to Use $\left(\mathrm{X}_{2}\right)$ & $0,514^{*}$ \\
\hline Perceived Ease of Use $\left(\mathrm{X}_{3}\right)$ & 0,792 \\
\hline$R$ adjusted $=0,848$ & \\
\hline$R$ square $\left(R^{2}\right)=0,870$ & \\
\hline $\mathrm{n}=100 ; *) \mathrm{P}<0,05$ & \\
\hline
\end{tabular}

\section{The Perspective of Perceived Usefulness onAttitude toward Using}

Based on results of analysis (Table 3), the perceived usefulness has positively affected on attitude toward using. The increasing perceived usefulness $1 \%$ will increase attitude toward using $45.6 \%$. It indicated that market segmentation of mozzarella cheese is native digital that has implemented preference toward strategy less for more and for the producers' perspectives that have preference of lowcost high impact. The adaptation level of both of them supports each other if the increase in marketing performance is carried out through engagement system of Instagram. The Instagram features, which are designed in accordance with the audiences' needs, have made the consumers prefer to purchase through landing page of Instagram which is integrated to website.

This result inline with Putra and Subawa (2021) statement, Instagram is an application to share photos with specific functions to upload, download, edit, add filter digital photos (photo effects), give comments, photo's title, location, like the photo, and share the photos to other social media. There are some features available in Instagram application as follows: Followers, Upload photos (Share), Title of the photo (Caption), Mention, Hashtag, Location, Like, and Comment. Moreover, Martinus and Chaniago (2017) also stated if Instagram is mostly used just as a prestige, in which the users follow the trend. But, following trends is not always bad; it 


\section{A.E. Kusumastuti.et al. /Instagram Platform Optimization By (Technology Acceptance Model) Approach As Improvement Of Mozarella Marketing Performance At Covid-19 Pandemic Era}

could even develop an optimistic and sportsman spirit to compete in goodness. Not only for personal interest, social media is also used by companies as a part of their effectiveness and efficient promotion strategies because it is easily accessed by anyone without expending too much money, so that promotion of their networks will be wider. Social media is a must of marketing for many companies, and it is the newest technique in marketing of a company.

Most of the millennial who success in online business, use the Instagram platform. It could encourage the hidden spirit of other millennial who have not tried and still hesitant to run their own business. Combination of visual and textual in Instagram becomes the most wanted channel which is used to market the influencer. For instance, the account of a successful figure or influencer will be able to raises the spirit within oneself because it is not uncommon to want oneself to be seen as great. Besides that, Instagram is able to connect us with families, relatives, and friends, as well as get accesss to important and up-to-date information, and many others.

\section{The Perspective of Intention to Use on Attitude toward Using}

Based on results of analysis, the behavioral intention to use have positively affected on attitude toward using. The increase of behavioral intention to use $1 \%$ will increase attitude toward using $51.4 \%$. Instagram assists the producers to interact with their consumers anytime. This strategy is important to observe progress of the consumers' behaviors so that producers will able to evaluate products and guarantee that the product is suitable with the consumers' desire and expectation.

Social networking sites are strong marketing tools used to connect among users and companies as users (Kyriakopoulou and Kitsios, 2017). Social media usually contain up-to-date information, including food products. Web-based media provides extraordinary opportunities to take advantage of informal promotions for the far-reaching audiences, support the exchange of buyer to buyer, and expand the brand awareness through large-scale interpersonal organization (Singha,et. al., 2021). If the producers could market a product as attractive as possible, it would be easier to attract consumers to try and purchase the product.In addition, the most important thing is observing the factual situation and condition so that the products would be sold out. Social media has capacity to place consumers on central role in business activities and provide new aspect for consumers to interact. Basically, social media has affected purchasing behavior of the consumers (Madni, 2014). It could direct the product to the right target and show good impression to consumers in order to retract them to purchase repeatedly. Producers should have initiatives in adjusting online and offline markets, particularly increasing the consumers' credibility through social media as promotion. Sosial media and marketplaces assist the farmers to reach the consumers in disruptive era (Putritamara,et.al.,2021).

\section{The Perspective ofPerceived Ease of Use onAttitude toward Using}

Based on results of analysis, the perceived ease of use positively affects on attitude toward using. The increase behavioral intention to use $1 \%$ will increase attitude toward using $79.2 \%$. It indicated that lazy economic had great impact on consumers' behaviors, such as mega shift or area change, which was experienced by the consumers during pandemic. It changes the consumers' habits, tastes, and lifestyle.

During pandemic, such change used to be happened; adaptive behaviors and attitudes become the main priority. Activities restriction has caused the communities do all activities at home, and almost the whole activities are conducted online. Ease of use, in which someone believes that a technology can be easily used and, in this case, the online site should be able to provide easiness to the users, so that they will believe that technology or system can be used easily without creating any trouble (Suhardi and Taufik, 2018). With just a finger touch, everything is available and resolved without spending a lot of efforts. As time goes by, the community have used to with the new habits which are easier and more practical. Habits tend to persist even after motivation or intention disappeared (Gardner,et al., 2012). As supported by technological advances that are increasingly capable, it is not impossible that everything can be done easily and practical. In implementing the technology, the barriers were not only caused by technical aspects, but also the users' behaviors (Rahmat, 2019). All of these underlie the new habits of community who tend to be a little lazy. 


\section{Conclusion}

Social media platform assists the producers to analyze the consumers' habits during pandemic. It indicates that when the producers are assisted by features in Instagram to engage with the consumers of Mozarella cheese, The community's acceptance to technology is getting higher as well as the consumers' perspectives which based on less for more due to producers use lo cost high impact, so that the price becomes affordable and conforms to strategies, which must be applied by the producers during pandemic when the purchasing power declined.

\section{Acknowledgement}

Special thanks to the Research Institution and Community Service (LPPM) Universitas Brawijaya, Malang, with SK No. 536.3.1./UN10.C10/PN/2021 for providing the research funding assistance to HPP (Novice Research Grant) in 2021.

\section{References}

[1] Ames, H., C. Glenton and S. Lewin. 2019. Purposive sampling in a qualitative evidence synthesis: a worked example from a synthesis on parental perceptions of vaccination communication. BMC Medical Research Methodology. 19(26): 1-9.

[2] Anwar, R. K., U. L. S. Khadijah., D. F. Sjoraida and M. Taufiq, R. The Impact of Using Instagram Social Media on Student Consumptive Behavior. Record and Library Journal. 6(1): 80-88.

[3] Campbell, S., M. Greenwood, S. Prior., T. Shearer., K. Walkem., S. Young and Danielle Bywaters. 2020. Purposive sampling: complex or simple? Research case examples. Journal of Research in Nursing. 25(8). https://doi.org/10.1177/1744987120927206

[4] Cardenas, J. C., E. Zabelina., J. G. Lanas., A. P. Fierro., and C. R. Galarza. Covid-19, consumer behavior, technology, and society: A literature review and bibliometric analysis. Technological Forecasting \& Social Change. 173 (2021) 121179.

[5] Crosta, A. D., I. Ceccato., D. Marchetti., P. L. Malva., R. Maiella., L. Cannito., M. Cipi., N. Mammarella., R. Palumbo., M. C. Verrocchi., R. Palumbo., A. D. Domenico. 2021. Psychological Factors and Consumer Behavior during The Covid-19 Pandemic. Research Article. https://doi.org/10.1371/journal.pone.0256095

[6] Davis, Fred D. 1989. Perceived Usefulness, Perceived Ease of Use, dan User Acceptance of Information Technology. Dalam MIS Quarterly, September, Vol. 13 Issue 3 p. 318-340.

[7] Doshi, A., L. Connally., M. Spiroff., A. Johnson and G. A. Mashour. 2017. Adapting the buying funnel model of consumer behavior to the design of an online health research recruitment tool. Journal of Clinical and Translational Science. 240-245. doi:10.1017/cts.2017.17.

[8] Shengyu, G., B. Slusarczyk., S. Hajizada., I. Kovalyova and A. Sakhbieva. 2021. Impact of the Covid-19 Pandemic on Online Consumer Purchasing Behavior. Journal of Theoretical and Applied Electronic Commerce Research. https://doi.org/10.3390/jtaer16060125

[9] Gardner, B., P. Lally and J. Wardle. 2012. Making health habitual: the psychology of 'habitformation' and general practice. British Journal of General Practice. 664-666.

[10] Ghozali, I. 2009. Aplikasi analisis multivariate dengan program SPSS. Edisi Keempat.Semarang: Universitas Diponegoro Press

[11] Jansen, B. J and S. Schuster. 2011. Bidding on The Buying Funnel for Sponsored Search and Keyword Advertising. Journal of Electronic Commerce Research. 12(1): 1-18.

[12] Kurniatullah, B. D. F and Y. T. C. Pramudi. 2017. The Influence of SocialMedia of Applied Intelligent System. 2: $29-36$.

[13] Kyriakopoulou, E and F. Kitsios. 2017. The influence of social media on consumers. ResearchGet. 62-66.

[14] Madni, G. M. 2014. Consumer's Behavior and Effectiveness of SocialMedia. Global Journal of Management and Business Research. 14(8): 56-62. 
A.E. Kusumastuti.et al. /Instagram Platform Optimization By (Technology Acceptance Model) Approach As Improvement Of Mozarella Marketing Performance At Covid-19 Pandemic Era

[15] Martinus, H and F. Chaniago. 2017. Analysis of Branding Strategy Through Instagram with Storytelling in Creating Brand Image on Proud Project. HUMANIORA. 8(3): 201-210.

[16] Putra, P. C. W. E and N. S. Subawa. 2021. Utilization of Instagram Online Shop in Millenial Generations. Enrichment: Journal of Management. 11(2): 330-333.

[17] Putritamara,J.A., Azizah,S , Ningsih,U.W., Haryono,M.B., and Sari,N.P. 2021. Strategi Pengembangan Wisata Agro Edukasi Berbasis Sapi Perah Era New Normal. Prosiding Hasil Penelitian dan Pengabdian Kepada Masyarakat Seminar Nasional II. ISBN: 978-602-50946-7-5 Fakultas Peternakan Universitas Jambi 2020 Sistem Produksi Peternakan Dan Perikanan Yang Berkelanjutan.

[18] Rahmat, T. 2019. The Influence of Perceived Ease of Use and Usefulness of The Academic Registration System on The Attitude of Using Online Study Plan Card (KRS). Journal of Theoretical and Applied Management. 12(3): 260-277.

[19] Rahmawati, R. N and I. M. Narsa. 2019. Actual Usage Penggunaan E-Learning dengan Technology Acceptance Model (TAM). Jurnal Inovasi Teknologi Pendidikan. 6(2): 127-136.

[20] Rashid, Y., A. Rashid., M. A. Warraich., S. S. Sabir and A. Waseem. 2019. Case Study Method: A Step-by-Step Guide for Business Researchers. International Journal of Qualitative Methods. 18: 113.

[21] Sayyida., S. Hartini., S. Gunawan and S. N. Husin. 2021. The impact of the covid-19 pandemic on retail consumer behavior. ATM. 5(1): 79-88.

[22] Sheth, J. 2020. Impact of Covid-19 on consumer behavior : Will the old habits return or die?. Journal of Business Research. 117 (2020) 280-283.

[23] Singha, A., Taranjit, S. V., R. Kaurc and D. Kaur. 2021. Impact of Social Media on Consumer Behaviour. Turkish Journal of Computer and Mathematics Education. 12(5): 1216-1225.

[24] Sitinjak, T. J. R., and Sugiarto. 2006. LISREL. Yogyakarta: Graha Ilmu.

[25] Sobari, M. R and H. Husnussalam. 2019. The Use of Discovery Learning Method to Improve Students' Writing Descriptive Text. Project Professional Journal of English Education. 2(2): 133139.

[26] Suhardi, D and N. Taufik. 2018. The Analysis of Ease of Use, Trust, and Website Quality towards Purchasing Decision in Lazada.co.id. Indonesian Journal of Business and Economics. 1(1): 38-48.

[27] Sumbaga, M. F and S. Ilena. 2021. The Impact of The Covid-19 Crisis on Consumer Behavior Online Shopping in Wisma Atlet 2 Quarantine Area, Jakarta. Psycho Idea. 19(2): 212-220.

[28] Syaifulah, J., M. Syaifudin., M. U. Sukendar., and J. Junaedi. (2021). Social Media Marketing and Business Performance of MSMEs During the COVID-19 Pandemic. Journal of Asian Finance, Economics and Business. 8(2): 523-531. https://doi. org/10.13106/jafeb.2021.vol8.no2.0523

[29] Tamrakar, A., Dr. J. P. Patra and D. Khadatkar. 2021. Student Performance Prediction by means of Multiple Regression. Turkish Journal of Computer and Mathematics Education. 12(12): 4126-4132.

[30] Turner, D. P. 2020. Sampling Methods in Research Design. In Headache. 60(1): 8-12. https://doi.org/10.1111/head.13707

[31] Uyanik, G. K and N. Guler. 2013. A Study on Multiple Linear Regression Analysis. Procedia Social and Behavioral Sciences. 106: 234-240.

[32] Wikarsa, L and A. Angdresey. 2021. Using Technology Acceptance Model to Evaluate the Utilization of Kolintang Instruments Application. Jurnal Pekommas. 6(1): (33-41). 